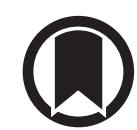

CrossMark

\section{A well-designed/conducted study on alpha-1 antitrypsin epidemiology not quoted}

\author{
To the Editor:
}

We read with interest the outstanding European Respiratory Society (ERS) statement on $\alpha_{1}$-antitrypsin deficiency (AATD) led by R.A. Stockley and M. Miravitlles with the collaboration of 13 European experts on the subject [1].

While the main objective of the manuscript was a broad update on the "state of the art" knowledge in the diagnostic and treatment of AATD-related pulmonary disease, other additional interesting aspects of this topic, including some epidemiological details, are also briefly discussed throughout the document.

For example, in the second paragraph of the section "Role and benefits of screening" it is stated that "few population-based studies ... randomly screened the general population", and the authors only mention those of CARroll et al. [2] in 1100 Irish subjects from the Trinity Biobank (a national buccal swab DNA collection selected at random from the electoral register constituted by individuals over the age of 18 years), and that of KACZOR et al. [3] performed in a 859 random sample of age- and gender-stratified residents, aged 20 years or older, from the municipal directory of Kraków, Poland.

However, although the authors of the ERS statement claim to have conducted a search until June 2016 in the most complete and reliable databases "with no language restrictions", another valuable study, unfortunately not widely reported and little known, has been omitted [4]. This pioneering study was the first, and likely the only one, performed on a truly representative sample of a general population composed by subjects of all ages (from newborns to older people living in the community), through a simple random sampling technique, with which each individual was chosen entirely by chance. This study was conducted in the central area of Asturias (Northern Spain) at the end of the 1990s, and it was initially published in Spanish with abstract in English, and then occasionally cited in other papers in English [5, 6].

The Asturian region where the study was carried out is a community located in the upper and middle basins of the Nalon river, with an extension of $646 \mathrm{~km}^{2}$ and a total population of 93642 inhabitants. To plan the appropriate sample size, a pre-estimation with the statistical program Rsigma (Horus Hardware) was used, and it provided a theoretically appropriate sample size of 1452 individuals. Then, using random numbers obtained by Rsigma, a number of lists of individuals were extracted from the census records of the county municipalities, being the final recruitment of 1116 individuals (76.9\%).

The mean \pm SD age of the random sample (male, 45\%; female, 55\%) was $46.2 \pm 29.9$ years with a range of 491 years. The characteristics of the sample are graphically shown in figure 1.

$\alpha_{1}$-antitrypsin serum levels of the selected subjects were measured by immunonephelometry and $\mathrm{Pi}$ phenotypes were determined by isoelectrofocusing in polyacrilamide gels. The frequency of $\mathrm{Z}$ allele was 19.7 per 1000 (one of the highest in Europe) and the allelic frequency of the S allele 99.9 per 1000 (one of the highest in the world, but similar to other found in the Iberian peninsula).

We hope that this comment will be helpful for possible future historical reviews of AATD.

Ignacio Blanco

Registro Español de Pacientes con Déficit de Alfa-1 antitripsina, Fundación Española del Pulmón, RESPIRA, SEPAR, Barcelona, Spain.

@ERSpublications

Recall of a historical study on the epidemiology of the alpha-1 antitrypsin gene http://ow.ly/yXAH30hZXiQ

Cite this article as: Blanco I. A well-designed/conducted study on alpha-1 antitrypsin epidemiology not quoted. Eur Respir J 2018; 51: 1702662 [https://doi.org/10.1183/13993003.02662-2017]. 

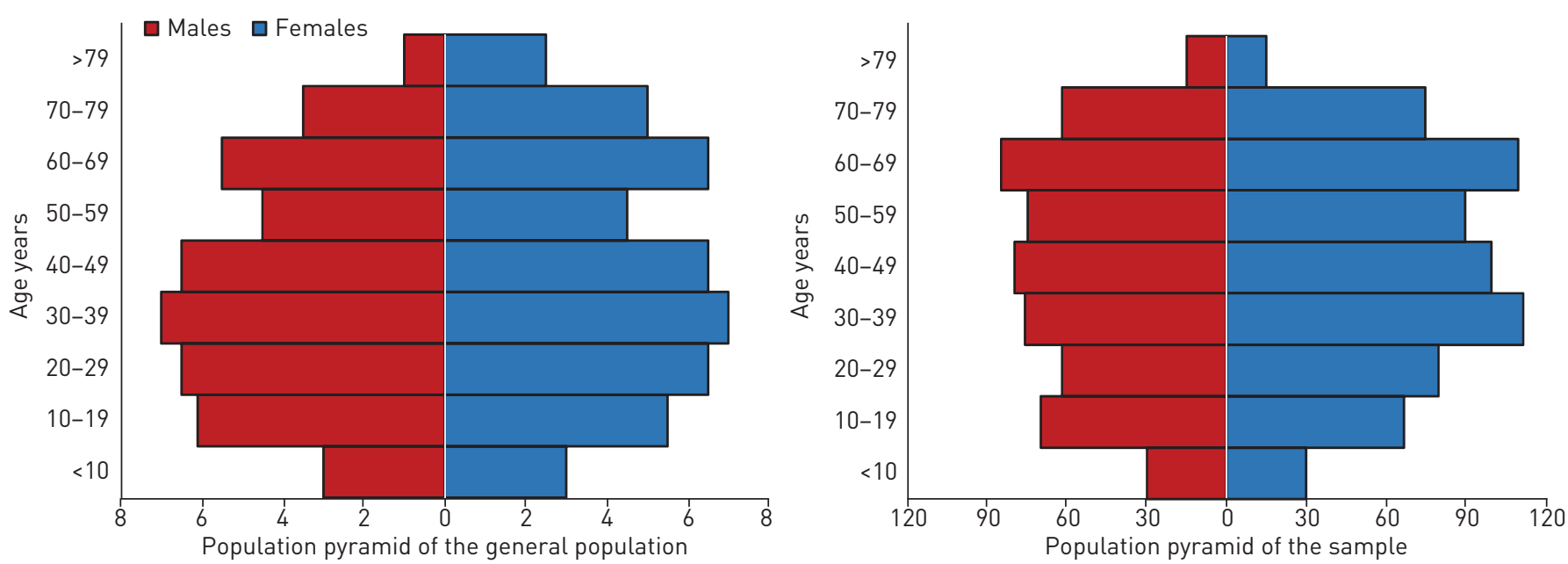

FIGURE 1 Population characteristics of the general population and the study sample [4].

Correspondence: Ignacio Blanco, Registro Español de Pacientes con Déficit de Alfa-1 antitripsina, Fundación Española del Pulmón, RESPIRA, SEPAR, Barcelona, Spain. E-mail: Ignablanco@yahoo.com

Received: Dec 202017 | Accepted after revision: Dec 292017

Conflict of interest: None declared.

\section{References}

1 Miravitlles M, Dirksen A, Ferrarotti I, et al. European Respiratory Society statement: diagnosis and treatment of pulmonary disease in $\alpha_{1}$-antitrypsin deficiency. Eur Respir J 2017; 50: 1700610.

2 Carroll TP, O'Connor CA, Floyd O, et al. The prevalence of alpha-1 antitrypsin deficiency in Ireland. Respir Res 2011; 12: 91 .

3 Kaczor MP, Sanak M, Libura-Twardowska M, et al. The prevalence of alpha-1-antitrypsin deficiency in a representative population sample from Poland. Respir Med. 2007; 101: 2520-2525.

4 Blanco I, Fernández E, Rodríguez MC, et al. [Allelic frequency of the gene of alpha-1-antitrypsin in the general population in a county in Asturias]. Med Clin (Barc) 1999; 113: 366-370.

5 Blanco I, Fernández E. Alphal-antitrypsin Pi phenotypes S and Z in Spain: an analysis of the published surveys Respir Med 2001; 95: 109-114.

6 de Serres FJ, Blanco I, Fernández-Bustillo E. Genetic epidemiology of alpha-1 antitrypsin deficiency in southern Europe: France, Italy, Portugal and Spain. Clin Genet 2003; 63: 490-509. 